\title{
Principal's Public Relation Strategy to Increase Society Belief
}

\section{Lalu Syauki MS1}

\author{
DOI: $10.35445 /$ alishlah.v13i2.950
}

\section{Info Artikel}

Keywords:

Public Relation;

Principal;

Society;

Teacher

Kata kunci:

Humas;

Kepala Sekolah;

Masyarakat;

Guru

\begin{abstract}
Public relations in this study is a way of interaction and communication between the school and the community in building trust and how the school promotes the school. The purpose of this study is to obtain in-depth information related to the principal's public relations strategy to increase public trust. The research method used a qualitative approach through surveys. Data were taken from observations, interviews and documents. The research participants were teachers, education staff, and the public relations team. Data analysis consisted of data reduction, data presentation, and conclusion making. The results of data analysis show that the principal already has a public relations strategy through media such as websites, social media (Instagram, Facebook, and YouTube channels).
\end{abstract}

\begin{abstract}
Abstrak
Public relation dalam penelitian ini merupakan cara interaksi dan komunikasi antara pihak sekolah dengan masyrakat dalam membangun kepercayaan dan cara sekolah mempromosikan sekolah. Tujuan dari penelitian ini mendapatkan informasi mendalam terkait dengan strategi public relation kepala sekolah untuk meningkatkan kepercayaan masyarakat. Metode penelitian menggunakan pendekatan kualitatif melalui survei. Data diambil dari observasi, wawancara dan dokumen. Partisipan penelitian adalah guru, tenaga kependidikan, dan tim public relation. Analisis data terdiri dari tahap reduksi data, penyajian data, dan pengambilan simpulan. Hasil analisis data menunjukkan bahwa kepala sekolah telah memiliki strategi public relation melalui media seperti websiter, media sosial (Instagram, facebook dan channel YouTube). Strategi yang telah diambil oleh kepala sekolah menunjukkan adanya
\end{abstract}

${ }^{1}$ MAN 2 Mataram, Indonesia

Email: lalusyaukims@gmail.com 


\section{INTRODUCTION}

School public relations has a very important role in building education administration. As the top leader in school management functions, it means that the principal is the main implementer in implementing public relations strategies to achieve educational goals. Public Relations is expected to plan and develop the quality of marketing and public relations activities to increase the number and quality of new student admissions. In addition, it is also expected to increase the number of publications in the mass media and control the news and information about schools in the media. The success of the public relations strategy is, of course, also influenced by the way the principal directs and understands the public relations process.

The public relations strategy in educational institutions with commercial companies has the same role and function, namely marketing their respective products. The basic context of public relations is a form of the communication concept of an organization with the public or society (Hermawan, 2020). Suppose it is associated with public relations in schools. In that case, the role of public relations from the principal is related to the way the principal communicates with the public relations team in the school so that the school can communicate the quality of the school to the community. Therefore, media is needed to implement a public relations strategy. Success in carrying out public relations tasks to reach the audience's attention is largely determined by his understanding of strategies to build relationships with the media and the skills and tactics of public relations practitioners in building relationships with the media (Hafizah, 2015). The media play a central role in informing the public about what is happening in the world (Happer et al., 2013). With advances in technology, social media is an example of a new paradigm in new communication related to public relations (Kent \& Li, 2019; Wiratmo et al., 2017).

Several previous studies show that public relations have a very important role in building cooperation between external parties and organizations, both commercial and non-commercial organizations. However, for schools, it is known that public relations have a different role from commercial organizations. Because using the PR team is more related to getting full support from the government, parents, community, private sector, or students for various educational programs in schools, this is a gap between this research and previous research. Public relations in schools usually play a role in increasing public or stakeholder trust regarding implementing education in schools. Public relations also usually builds an image of the quality of good school education. Every school, whether public or private, has a different public relations strategy. However, principals direct the public relations team to use various media, organize activities, offer scholarships or other promotions to attract students. As in Madrasah Aliyah Negeri 2 Mataram, they do different ways to promote the quality of school education so that people entrust their children to attend the schools they lead.

Therefore, public trust is the end of school public relations communication activities. Thus, school public relations must have the right strategy and effective public relations communication (Amalia, 2020). School public relations duties are also usually related to students' employability to the satisfaction of parents (Swart, 2014). So, the principal must ensure how this information or message of satisfaction from parents becomes a good value to increase public confidence about the quality of education.

MAN 2 Mataram, as one of the model schools in Mataram must build the right public relations concept so that the information conveyed to the public is accurate and by the facts. To achieve this goal, the principal, as the highest leader in the school, must be able to carry out dialogue as a form of public relations strategy (Behbahani, 2011). So, the principals need leadership skills to implement the public relations strategy (Piaw et al., 2014). Principal leadership competencies can also influence the social behavior of teachers and teams in building communication to realize public relations (Yasin \& Mustafa, 2020). From the results of the analysis of observations in the preliminary study, the principal tried to hold discussions with the teachers or administration at MAN 2 Mataram to 
collect their data about the lack of a school public relations strategy. The discussion results concluded that the website that has been created has not fully displayed information about schools, and activities that involve all parties must be done more and adapted to current needs.

Therefore, this study presents a different concept from previous research on public relations strategies at the MAN 2 Mataram school. Moreover, research related to public relations strategies in schools has not been studied more deeply, so this research becomes interesting and urgent because schools need all parties' cooperation regarding the delivery of information about the quality of school education to build public trust. In addition, another reason for carrying out this research is the concept or paradigm of school or public partnerships, which should be able to make the community a promotional medium. However, every strategy taken by the team and the principal as the person responsible for public relations must be planned very well. Planning related to the public relations strategy must be taken from various opinions of teachers, education staff, school committees, and the public relations team.

Therefore, this study aims to obtain the principal's public relations strategy in building public trust. Thus, this research is expected to contribute to developing public relations strategies that can build a better school image, and the community has a high level of trust in schools.

\section{METHOD}

The participant of study was teacher, administrator, and public relation team. They were ten people ( $\mathrm{M}=5$ and $\mathrm{F}=5)$. They gave their opinion about the process of public relations to promote the quality of education in the school. This study used a qualitative approach through a survey. Survey research is defined as "collecting information from a sample of individuals through their responses to questions" (Ponto, 2015). It can be used observation and interviews to collect data. This study observed the phenomenon in the public relation strategy concept in school through the teacher's opinions.

Data is collected through observation, document, and interview. The observation is done to observe some event of school promotion, while the document is taken from the event or promotion evaluation report. The interview is done with the teacher, administrator, and public relations team. The technique analysis data used qualitative descriptive, which used three steps: data reduction data, data display, and taking conclusion.

\section{FINDINGS AND DISCUSSION}

The result of data interviews, observations, and documents are presented in narrative form as findings related to public relations strategies that school principals must own. The data is taken from observations and documents related to website and social media designing. At the same time, the interview data is taken to know the role of the school principal in public relations strategy.

Some of the strategies that schools have carried out to develop the function of public relations are;

1. School has created a school website with the Url: "http://www.manduamataram.sch.id/" which contains information related to school profiles. However, the website still needs to be improved with complete information.

2. Designing social media to convey information about the school:

a. Facebook (https://www.facebook.com/pg/fahrum2m/posts/)〉

b. Instagram (https://www.instagram.com/humas_man2mataram/?hl=en)

c. YouTube Channel

(https://www.youtube.com/channel/UCDee3hGDUJLXVpYqdOUsNoQ/featured?view _as=public)

The media presented various school achievements that have been carved out by students, various activities to increase student competence, and community service. So, the principal at MAN 2 Mataram has used the media as a communication strategy in public relations which is currently considered very effective. Several studies have shown that fair use of digital media is essential to 
understanding and responding to the expectations of different audiences and to be able to improve communication effectiveness (Linke \& Zerfass, 2013; Kent \& Saffer, 2014; Moreno et al., 2015). Professional PR will manage information well through social media (Navarro et al., 2017). Moreover, technological advances have been used as part of the implementation of education which is not only used for teaching and learning activities.

The interviews with teachers and the public relations team at MAN 2 Mataram also concluded that schools must establish general partnerships and present the quality values of providing good education to parents, stakeholders, and the community. The role of the principal in implementing the public relations strategy at MAN 2 Mataram, among others;

a. Promoting input from the community regarding various educational program developments

b. Anticipating image problems; provide solutions to problems that arise from various parties related to achieving educational goals.

c. Handle all aspects of publication, e.g., external newspapers and internal bulletins, websites. However, the internal newsletter has not been achieved and designed. Meanwhile, publications through external newspapers are always involved in various school activities that show student achievements.

d. Act as primary contact for the media: write news releases; work to get media coverage of regional news

e. Designing objective information materials for the budget

f. Design for all levels of communication, including writing a crisis communication plan

g. Conduct public relations research, surveys, and opinion polls; interpret educational outcomes that have been achieved for management

h. Build awareness to teachers, administrative staff, or other school residents that public relations are an important aspect in increasing public trust so that the quality of education can continue to advance

Because the current public demand for educational institutions is accountability, all information about schools must be conveyed with truth values. Educators have a responsibility to provide more detailed information about schools. Another thing taken into consideration from the school's public relations strategy that school principals must consider is the challenge of the need to build communication and relationships with the community. Public relation is a relationship pattern built between individuals to build reciprocal interactions to persuade each other. Public Relations is an important element in building self-image, groups, organizations, or companies, though. In the study of communication, Public Relations becomes the function of interpersonal communication. Because here, it involves two or more individuals who interact with each other (Seniwati, 2016). This relationship is also related to the pedagogical approach that strengthens education with ethics or rules for collaboration in professional development. It means that school public relations must be able to build professionals (Eschenfelder, 2011).

This professional concept is a must for school principals so that public relations strategies can be implemented properly in achieving educational goals. Academically, public relations in the school's organizational structure can be realized optimally when the school understands the needs. In addition, the principal as a leader in carrying out his duties as the person in charge of the success of public relations with two-way communication, because public relations in the organization is the center and its role can have a major impact on public trust. From the data found, it is known that the community around the school also provides great participation, especially the school committee, which always actively participates in various activities.

Thus, the general goal of public relations at MAN 2 Mataram is to help provide satisfaction to the community (parents, students, school committee members, staff, relevant stakeholders, and alumni) and pride the school's achievements so far. This means that it can be said that the principal's strategy in developing public relations has had a major impact on improving the quality of schools. 
School public relations is a joint public relations effort of everyone in the school. The awareness of everyone in the school is the main key as a mirror of the school culture.

Therefore, principals must face challenges in public relations activities, especially in unifying concepts from all school members because various good public relations activities are carried out through the opinions or input of all parties in the school. Teachers, students, education staff, and school cleaners are marketers who will market and convey various information to the public. The principal must be able to build communication with them to convey information to the community correctly so that public trust can continue to increase in the school. At MAN 2 Mataram, everyone has been invited to be involved in various public relations activities. Thus, the principal's public relations strategy is not only oriented through the media but how to take advantage of the strengths of everyone in the school as a facilitator in building communication and public trust. Thus, it is concluded that school public relations are oriented to imagery and how all levels of society trust them. School public relations also means conveying truth values related to school quality so that the community has complete trust in the school

\section{CONCLUSION}

The public relations strategy of the principal has a considerable influence on the school's public relations process, especially since the MAN 2 Mataram school is a pilot school in Mataram. In developing a public relations strategy, the principal is to utilize media (social media) and media technology (website) and present information on student achievement that students have carved. The school also carries out various promotional activities involving the community and parents. In addition, the principal also always conducts ongoing evaluations to find out the development of public relations work. School principals have used various strategies to foster public interest and trust in MAN 2 Mataram. In every public relations plan designed, the principal tries to involve all parties, such as teachers, education staff, and teams. It has an impact on the participation of all school members. Effective school public relations build trust, build a respected brand, and build school expertise are powerful tools in marketing and communications.

This research is still limited on the principal's public relations strategy to build public trust in the school through the perspective of school members such as teachers, education staff, and teams. Therefore, these limitations can be redeveloped for the next researcher that focuses on developing or analyzing a public relations model's needs for school marketing. This research can also be a recommendation for the MAN 2 Mataram school to improve the public relations strategy that has been used in schools. In addition, the results of this study are also important inputs for school principals in carrying out their leadership, specifically for public relations strategies.

\section{REFERENCES}

Amalia, V. (2020). Strategi Komunikasi Humas Dalam Meningkatkan Public Trust Di Perguruan Tinggi (Studi Kasus di Universitas Nurul Jadid, Paiton, Probolinggo). AL-TANZIM: Jurnal Manajemen Pendidikan Islam, 4(1), 13-23. https://doi.org/10.33650/al-tanzim.v4i1.812

Behbahani, A. (2011). Educational leaders and role of education on the efficiency of schools principals. Procedia - Social and Behavioral Sciences, 15, 9-11. https://doi.org/10.1016/j.sbspro.2011.03.040

Eschenfelder, B. (2011). The role of narrative in public relations ethics pedagogy. Public Relations Review, 37(5), 450-455.

Hafizah, E. (2015). Strategi Public Relations Dalam Membangun Hubungan Dengan Media. AlHikmah, 8(2). https://doi.org/10.2426o/al-hikmah.v8i2.80

Happer, C., Philo, G., \& Philo, G. (2013). The Role of the Media in the Construction of Public Belief and Social Change. Journal of Social and Political Psychology, 1(1), 321-336. https://doi.org/10.5964/jspp.v1i1.96

Hermawan, E. (2020). Strategi Public Relations Kementerian Pariwisata dan Ekonomi Kreatif dalam Membangun Media Relations. JMK (Jurnal Manajemen Dan Kewirausahaan), 5(2), 140. https://doi.org/10.32503/jmk.v5i2.1028

Kent, M. L., \& Li, C. (2019). Toward a normative social media theory for public relations. Public 
Relations Review, 101857. https://doi.org/10.1016/J.PUBREV.2019.101857

Kent, M. L., \& Saffer, A. J. (2014). A Delphi study of the future of new technology research in public relations. Public Relations Review, 4O(3), 568-576. https://doi.org/10.1016/J.PUBREV.2014.02.008

Linke, A., \& Zerfass, A. (2013). Social media governance: regulatory frameworks for successful online communications. Journal of Communication Management, 17(3), 270-286. https://doi.org/10.1108/JCOM-09-2011-0050

Moreno, A., Navarro, C., Tench, R., \& Zerfass, A. (2015). Does social media usage matter? An analysis of online practices and digital media perceptions of communication practitioners in Europe. Public Relations Review, 41(2), 242-253. https://doi.org/10.1016/J.PUBREV.2014.12.006

Navarro, C., Moreno, A., \& Al-Sumait, F. (2017). Social media expectations between public relations professionals and their stakeholders: Results of the ComGap study in Spain. Public Relations Review, 43(4), 700-708. https://doi.org/10.1016/J.PUBREV.2016.12.008

Piaw, C. Y., Hee, T. F., Ismail, N. R., \& Ying, L. H. (2014). Factors of Leadership Skills of Secondary School Principals. Procedia - Social and Behavioral Sciences, 116, 5125-5129. https://doi.org/10.1016/j.sbspro.2014.01.1085

Ponto, J. (2015). Understanding and Evaluating Survey Research. Journal of the Advanced Practitioner in Oncology, 6(2), 168. /pmc/articles/PMC4601897/

Seniwati, S. (2016). Peran Public Relation Dan Media Relation Dalam Membangun Citra Positif Hotel Grand Clarion Kendari. Jurnal Ilmu Komunikasi UHO : Jurnal Penelitian Kajian Ilmu Komunikasi Dan Informasi, 1(2). http://ojs.uho.ac.id/index.php/KOMUNIKASI/article/view/1455

Swart, C. (2014). An assessment of work-integrated learning for public relations in an open distance learning context. Public Relations Review, 4O(2), 387-396. https://doi.org/10.1016/J.PUBREV.2013.10.008

Wiratmo, L. B., Irfan, N., \& Kuwatono. (2017). Website Pemerintah Daerah Sebagai Sarana Online Public Relations. Jurnal ASPIKOM, 3(2).

Yasin, B., \& Mustafa, F. (2020). The Correlation between school principal leadership competence and teachers' social behaviours. In IRJE |Indonesian Research Journal in Education| |Vol (Vol. 4, Issue 1). https://doi.org/10.22437/irje.v411.9093 